\title{
Ocular System Dosing Unit
}

National Cancer Institute

\section{Source}

National Cancer Institute. Ocular System Dosing Unit. NCI Thesaurus. Code C69086.

A dosing unit equal to the amount of active ing redient(s) in an ocular system. 